\title{
Disappearing Wildlife and Growing Deserts in Jordan
}

\author{
By Guy Mountfort
}

The disastrous losses in recent years in the wildlife of Jordan are described by Guy Mountfort, ornithologist and leader of the 1963 British expedition * which was invited by H.M. King Hussein to study the situation in eastern Jordan. The chief recommendations in the expedition's report, which have been accepted by the Jordanian Government, include the setting up of several national parks with strict protection of wildlife and vegetation. One small but vital recommendation is the provision of kerosene to the Beduin for fuel to save the last remnants of trees and shrubs. Photographs by Eric Hosking, who directed this aspect of the expedition, are on plates 9-15, following page 234 .

$T^{n}$ the spring of 1963 H.M. King Hussein invited a British expedition to 1 conduct an extensive study of the desert and mountains to the east of the Rift in Jordan. This wild and little known region represents nearly nine-tenths of Jordan's land-mass, yet supports only one twentieth of its population. Most of it is barren desert, inhabited only by the Beduin. Although many previous studies had been made of Jordan's vegetation, climate and topography, remarkably little was known about the status of its wildlife, apart from rumours that it was disappearing rapidly. Among the twelve members of the expedition were Max Nicholson, DirectorGeneral of the Nature Conservancy, who was deputy leader and in charge of the ecological studies, and Sir Julian Huxley, in charge of archaeology and adviser on conservation. Botanical studies were made by Professor Duncan Poore, of the University of Kuala Lumpur, and Jan Gillet, of the Royal Botanic Gardens, Kew. A team of ornithologists was led by James Ferguson-Lees, while photography and filming were directed by Eric Hosking.

The expedition had the following objectives :

(1) To fill certain major gaps in available information, especially by systematic collecting of plants, with ecological data on their distribution ; and an initial reconnaissance of the fauna and particularly of the birds as the only main " indicator group " which could be effectively worked in the time available.

(2) To prepare an extensive cinematic and photographic record, in colour and black and white, of the present state of the landscape, its conservation and its fauna and flora, as a supplement to descriptive and cartographic material, and as a basis for demonstrating conditions, problems and remedies.

(3) To review and bring into focus, in the light of rapidly developing knowledge elsewhere in the world, the interpretation to be placed on

* A book about this expedition, by Guy Mountfort, "Portrait of a Desert ", is to be published in the autumn by Collins. 
previous work in Jordan and the conclusions to be drawn, especially in regard to economic and ecological trends.

(4) To examine Jordan's wealth of antiquities and consider what these might be able to contribute as potential assets to the national economy.

(5) In the light of this work, to offer recommendations to enable the Jordan Government to take full advantage, under a co-ordinated long-term plan, of the various potentialities represented by the natural resources of the country.

Starting from Amman, the expedition first studied the relatively fertile valley of the Zarqa River and the mountains of Gilead in the north; then moved eastward to the Azraq oasis, which is the only permanent standing water in several thousand square miles of desert. After ten days at the oasis the expedition moved south along the mountains bordering the Dead Sea, stopping for a few days at Karak and Nijil (5,500 feet above sea level). Diversions were made to the Dead Sea shore and to the ancient Nabataean city of Petra. The final base was in the spectacular Wadi Rum, from which excursions were made to Aqaba, on the Red Sea, and to El Jafr in the southern desert. In all, the expedition covered about 3,000 miles, chiefly over rough desert tracks. Three Land-Rovers and a one-ton truck were generously provided by the Jordan Government and every facility was given by the desert army and the hospitable Beduin tribes. Two vehicles which were wrecked in the course of the expedition were immediately replaced and our five temporary casualties were soon in the field again.

\section{Severe Losses This Century}

Jordan's losses of wildlife, particularly among the larger animals, have been disastrous. The Asiatic lion, the chief joy of the Umayyad hunters in Biblical times, had disappeared early in the fifteenth century. The big losses began to be noticed around 1900, when the last of the roe deer, addax antelope and crocodile were recorded. The wild ass was killed off by 1920 and the fallow deer by 1922 . The Syrian bear was exterminated in the 1930's. The last ostrich was seen near Jebel Tubaiq in 1932 and Jordan's last oryx was probably shot before 1950 . The cheetah may now have been lost, as there have been no records since a female was shot in 1962 and her cub taken. A few ibex survive in steadily decreasing numbers in the more inaccessible mountains, but unless given effective protection they will not be there for long. Wolves also are beginning to die out.

There are two species of gazelles in Jordan, the Arabian gazelle Gazella arabica, which inhabits the open desert, and the smaller Dorcas gazelle $G$. dorcas, which prefers the foothills. Ten years ago both species were still so numerous that no one could have believed that their survival was threatened. Five years ago their numbers were declining at an alarming rate, not only in Jordan but throughout the Arab world. In all our searching we saw only a single party of eight Arabian gazelles, scampering off into the stony desert far to the east of Azraq. Obviously there are still a few gazelles left in Jordan. We came across five in miserable captivity. These had been picked up as calves by the Beduin and sold into captivity, to end their days with ropes around their delicate necks. A standard price of five dinars (about $f 5$ ) appears to have been established and the Beduin are not slow to take advantage of the demand. The habit of selling calves 
is probably not a major factor in the survival of the gazelles. The chief cause of the catastrophic decline in Jordan is the raiding parties from the neighbouring oil states, who, having killed off their own game, now cross the largely unguarded desert frontiers to continue the motorised slaughter. The Jordanian Beduin cannot be blamed, as very few of them have cars. We were repeatedly told of these hunting raids in the regions of El Jafr and Rum, which are not far from the Sa'udi Arabian frontier. The other major factor, and this needs to be said, is that, although admirable laws have been devised to regulate hunting in Jordan, they are not enforced. We heard far too many stories of "rich men from Amman and Army officers" shooting exhausted animals from cars. Gazelles have also been machine-gunned by fighter aircraft in several countries of the Middle East.

\section{Houbaras could not be Found}

The situation of the houbara bustard is very similar to that of the gazelles. This magnificent creature, as handsome though not as large as the European great bustard, is essentially a desert bird, demanding wide expanses of undisturbed terrain for breeding. We had a particular reason for wanting to study it, because of the excitement created when a vagrant reached Britain in November, 1962. It was the first recorded for seventy years. We gave the houbara top priority for study in Jordan, and were confidently told there would be no dificulty in locating it. Whole days were devoted to scouring regions where houbaras were supposed to be nesting. Not one was seen. All we found in the north was a fresh feather clearly belonging to the species; in the south we found a nest, with two eggs which had just been sucked by a goatherd!

We were unfortunately not able to judge the status of the six species of sandgrouse which are said to occur in Jordan. Normally they should have been numerous, but they are very dependent on water and severe drought had driven them farther north. However, we were told that the " pigeons," as the Beduin call them, had been very plentiful on migration in 1962 . We identified the spotted, pintailed and black-bellied sandgrouse; the others which should occur in Jordan are the coroneted, small pintailed and close-barred. Although large numbers of sandgrouse are shot on migration, when their dense flocks provide relatively easy targets, they gain some protection from their rapid flight and erratic wanderings. Hunting is probably not yet a major factor in their survival in Jordan.

\section{Forests Cut for Railway Fuel}

Closely allied to Jordan's losses of wildlife has been the progressive and now accelerating loss of vegetation. The Middle East contains the largest areas of man-made desert in the world. In Jordan one sees the clearest evidence of the means by which this is brought about. Almost none of the country's once extensive original forest now remains. The process of denudation was gradual up to the outbreak of the First World War. It was then greatly aggravated by the Turkish army, which stripped Jordan almost bare of trees in order to fuel the locomotives of the Hejaz railway. No country has ever suffered such a determined onslaught on its forest. Today large trees are completely absent from the greater part of the country. The steady drain on the smaller vegetation is continued by the 
Beduin, who every day cut hundreds of acres of desert shrublets for their camp fires ; and by the ravages of millions of hungry goats which swarm everywhere. As the vegetation disappears, wind and water rapidly erode the top soil and the desert advances.

Among the many small animals which were studied by the expedition were the hairy-footed jerboas and the Palestine mole-rats. The latter are almost blind, sausage-shaped little creatures which tunnel into the hardest ground with their long, permanently growing incisors. They do great damage to root crops and grain in Jordan. So powerful is their tunnelling that they often throw up their " mole-hills" in metalled roads. The most interesting small mammal seen was undoubtedly the little-known Arabian form of the sand cat Felis margarita, which was observed in the desert at Rum. The botanists and ornithologists recorded a number of species not previously known to occur in Jordan. Among the 600 plant species collected was a strange, evil-smelling stapeliad of the genus Caralluma, which is probably new to science. Its fleshy flowers are covered with minute hairs, which the slightest breeze keeps in motion. This movement and the smell, like carrion, attract the flies which pollinate the flowers. Of the 216 species of birds recorded, 96 were breeding. The most exciting discovery was a small colony of lesser sand plovers Charadrius mongolus nesting near Azraq, which is some 2,000 miles west of the previously recorded breeding range of this species. In the realm of ecology the expedition produced the first large-scale appreciation yet made in a huge area of varying deserts and mountains, of the inter-relationships of distribution and numbers of bird species to vegetation, soil-types, rainfall and other factors. The World Wildlife Fund and the International Union for Conservation of Nature are now armed with urgently needed information about the status of the most seriously threatened mammals and birds of Jordan.

\section{Proposed National Parks}

In a detailed report to the Hashemite Government of Jordan a number of recommendations were made concerning wildlife conservation. The key to our proposals was the creation of several National Parks in which the vegetation and animals could recover under strict protection. These would be centred on the Azraq oasis, the Rift escarpment and the colourful jebels of Rum. Each of the areas would embrace a number of Jordan's magnificent archaeological treasures, such as the early Umayyad hunting lodges and Crusader castles. Each would also include some of the most spectacular scenery in the world. The picturesque Beduin would continue to have access to these areas, so that visitors could enjoy the spectacle of their way of life and their traditional sports such as falconry and camel racing. The Beduin would, however, be asked to accept the provision of kerosene instead of brushwood for fuel and the avoidance of over-grazing within the parks. These minor restrictions would be a small price to pay for the assured preservation of their tribal customs in a changing world. The recommendations have since been accepted by the Jordan Government. Their implementation will not only represent a great step forward in conservation, but a major economic asset in the development of a prosperous tourist industry. 